\title{
IMPLiCATIONS OF WEEDS OF GENUS EUPHORBIA FOR CROP Production: A Review ${ }^{1}$
}

\author{
Implicações de Plantas Daninhas do Gênero Euphorbia na Produção de Culturas: Uma Revisão
}

\author{
TANVEER, A. ${ }^{2}$, KHALIQ, A. ${ }^{3}$, JAVAID, M.M. ${ }^{4}$, CHAUDHRY M.N. ${ }^{5}$, and AWAN I. ${ }^{6}$
}

\begin{abstract}
The genus Euphorbia comprises about 2000 species ranging from annuals to trees, including $\mathrm{C}_{3}, \mathrm{C}_{4}$, and CAM species. Euphorbia species widely studied in agriculture includes E. antiquorum, E. carollata, E. dentata, E. dracunculoides, E. esula, E. geniculata, E. granulata, E. helioscopia, E. heterophylla, E. hierosolymitana, E. hirta, E. maculata, E. microphylla, $E$. nerifolia, E. piluifera, E. pulcherrima, E. royleana, E. supine, and $E$. thiamifolia. These species have been reported mainly in field crops/vegetables, orchards, pastures, and rangelands. Euphorbia plants may present allelopathic effect over desirable cereals, pulses, oilseeds, vegetables, forage plants, and nitrifying bacteria, posing a serious threat to livestock production on open range lands through the release of allelochemicals from roots, stems, leaves, and inflorescence in the rhizosphere. Leaves are reported to be more toxic than other plant parts. Competition of Euphorbia spp. against crop plants is the most important crop yieldlimiting factor. The critical period for Euphorbia competition with crops is reported to take place between 17 to 70 days after emergence for most crops, depending on root development during the initial crop growth stage, crop height, tillering or branching capacity, whether weeds emerge at the same time as the crop or later after crop emergence; how quickly crop canopy develops and also on Euphorbia species. A yield reduction of 4-85\% has been reported in field crops with different Euphorbia species and distinct occurrence densities. Euphorbia species decrease herbage production by 10 to $100 \%$ in pasture and rangelands, with many acting as natural insecticide, fungicide, nematidicide, immunopotentiator, or immunosuppressor.
\end{abstract}

Keywords: competition, allelopathy, crops, pastures, livestock, plant protection.

RESUMO - O gênero Euphorbia compreende cerca de 2.000 espécies, que variam de plantas anuais a árvores, incluindo C3, C4 e espécies CAM. As espécies de Euphorbia amplamente estudadas na agricultura incluem $\boldsymbol{E}$. antiquorum, E. carollata, E. dentata, E. dracunculoides, E. esula, E. geniculata, E. granulata, E. helioscopia, E. heterophylla, E. hierosolymitana, E. hirta, E. maculata, E. microphylla, E. nerifolia, E. piluifera, E. pulcherrima, E. royleana, $\boldsymbol{E}$. supina e $\boldsymbol{E}$. thiamifolia. Essas espécies têm sido relatadas principalmente em culturas de campo, legumes/pomares, pastagens e pastagens. Plantas de Euphorbia podem apresentar efeito alelopático sobre cereais, leguminosas desejáveis, oleaginosas, vegetais, plantas forrageiras e bactérias nitrificantes, o que representa uma séria ameaça para a produção de gado em terras abertas, através da liberação de aleloquimicos de raizes, caules, folhas e inflorescências na rizosfera. As folhas são mais tóxicas do que outras partes da planta. A competição de Euphorbia spp. com plantas de cultivo é o mais importante de todos os fatores que limitam a produtividade das culturas. O período crítico da competição de Euphorbia com as colheitas é relatado como sendo entre 17 e 70 dias após a emergência para a maioria das culturas, dependendo do desenvolvimento de raizes durante o estádio inicial de crescimento da cultura, da altura da cultura, do afilhamento ou ramificação de capacidade, se as plantas daninhas surgem ao mesmo tempo com a cultura, ou mais

Recebido para publicação em 11.7.2012 e aprovado em 23.1.2013.

2 Department of Agronomy, University of Agriculture, Faisalabad, Pakistan, <drasiftanveeruaf@hotmal.com>, corresponding author; ${ }^{3}$ Department of Agronomy, University College of Agriculture, University of Sargodha, Pakistan. ${ }^{4}$ University College of Agriculture and Environmental Sciences, The Islamia University of Bahawalpur, Pakistan, ${ }^{5}$ Department of Agronomy, Gomal University, D.I. Khan, Pakistan. 
tarde, após a emergência da cultura, da rapidez com que o dossel da cultura se desenvolve e também das espécies desse gênero. Uma redução no rendimento de 4-85\% tem sido relatada em colheitas de campo com diferentes espécies de Euphorbia e densidades distintas de ocorrência. Essas espécies diminuem a produção de forragem de 10 a 100\% em pasto e pastagens. Muitas delas atuam como inseticida natural, fungicida, nematidicide, imunopotenciador ou imunossupressores.

Palavras-chave: competição, alelopatia, lavouras, pastagens, pecuária, proteção de plantas.

\section{INTRODUCTION}

The genus Euphorbia, belonging to the Euphorbia family, comprises about 2000 species ranging from annuals to trees (Shi \& Jia, 1997). The genus Euphorbia is a structurally and physiologically diverse taxon and includes $\mathrm{C}_{3}, \mathrm{C}_{4}$ and CAM species (Downtown, 1971). To date, more than $60 \mathrm{C}_{4}$ species have been detected within the genus (Downtown, 1975; Raghavendra \& Das, 1978), and 18 species have been reported to have CAM physiology (Szarek, 1979). The extensively investigated species of Euphorbia includes Euphorbia dentata (toothed spurge) in corn, soybean and sunflower (Juan et al., 1996, 2003); E. esula (leafy spurge) in range and recreational lands (Dunn, 1979; Steenhagen \& Zimdahl, 1979; Singh et al., 2000), monocrop land habitats (Selleck et al., 1962); E. dracunculoides (dragon spurge) in wheat, chickpea and mustard (Singh et al., 1995; Ponia et al., 1997; Shanee et al., 2011); E. geniculata ( painted spurge) in orchards of loquat, mango, guava, citrus group, grapes and ber (Zizyphus jajuba) (Sindhu \& Bir, 1987), soybean and chickpea (Jain \& Tiwari, 1993; Mishra \& Singh, 2003); E. granulata (prostrate spurge) in lawn, cultivated field, onion (Hussain, 1980; Sadaqa et al., 2010); E. helioscopia (sunspurge) in wheat, lentil, chickpea, potato and pea (Ghafoor \& Shad, 1990; Tanveer et al., 2010; Bharat \& Kachroo, 2007, 2010) and as a medicinal plant (Jiangbo et al., 2010); E. heterophylla (wild poinsettia or painted spurge) in Kersting's ground bean (Macrotyloma geocarpa), soybean, cowpea, cotton, sugarcane, peanut (Harger \& Naster, 1980; Akobundu \& Agyaka, 1987; Eniola \& Fawusi, 1989; Adelusi \& Akamo, 2006); $E$. hierosolymitana (spurge) in wheat, orchards (Romman et al., 2010); E. hirta (Pill-bearing spurge) in rice - mung+sesame system (Ramanjaneyulu et al., 2006); chilli, maize, mustard (B. juncea) (Sandhu et al., 1999; Rajput et al., 2003; Singh \& Agarwal, 2004; Kumar et al., 2009; Jabeen \& Ahmad, 2009); E. maculata (spotted spurge) in cotton, soybean (Bannon et al., 1978; Dale \& Chandler, 1979; Dunn, 1979); E. microphylla in citrus (Josan et al., 2003); E. supina (prostate spurge) in cotton, soybean (Bannon et al., 1978; Dale \& Chandler, 1979; Dunn, 1979); Euphorbia spp. in rice (Kumar et al., 2009; Yadav et al., 2009), and E. thiamifolia (thyme-leaf spurge) in Cajanus cajan, Vigna radiata, V. uriculata and Cicer arietinum (Kumbher \& Dabgar, 2010, 2011). The present review discusses the competition and allelopathic effects of genus Euphorbia weeds on other weeds, crops, pastures and livestock along with their plant protection potential.

\section{Euphorbia spp. competition with crops}

Weed density, duration, species, area of influence and agro-management practices are used to determine the extent of damage caused by the competition of a weed species within a crop. Duration of weed competition, often called the critical period, defines the maximum period in which weeds can be tolerated without affecting final crop yields. A 10 -wk E. heterophylla - free period was required to prevent peanut (Arachis hypogaea) yield losses (Bridges et al., 1992). A period of 3-4 weeks after planting is the critical period of $E$. heterophylla competition in cowpea (Vigna unguiculata) (Olorunmaiye \& Ogunfoloji, 2002). The critical period for $E$. heterophylla competition in soybean was reported to be between 17 to 44 days after emergence (Meschede et al., 2002), while Adelusi et al. (2006b) stated that the critical weed free period falls between 28 to 38 days in E. heterophylla - soybean competition.

Yield losses by a specific weed vary from crop to crop. Soybean and peanut have suffered 
yield losses of 30 and $50 \%$, respectively, due to the presence of E. heterophylla (Bannon et al., 1976; Nester et al., 1979; Bridges et al., 1992; Willard \& Griffin, 1993). Competition for more than 2 weeks resulted in $8 \%$ or greater soybean yield reduction by $E$. heterophylla (Bridges et al., 1992). Meschede et al. (2002) stated that presence of E. heterophylla in soybean during the whole cycle caused a yield loss of $5.15 \mathrm{~kg} \mathrm{ha}^{-1}$ per day. According to Kissmann (1992), yield losses in soybean due to E. heterophylla can reach up to $80 \%$ depending on management practices. It could be attributed to higher water-use efficiency and net photosynthesis of $E$. heterophylla than soybean (Procopio et al., 2004 ). Olorunmaiye $\&$ Ogunfolaji (2002) reported reduction in growth, yield and yield components of cowpea with increase in E. heterophylla competition duration from 3 to 6 weeks after planting.

Willard et al. (1994) studied E. heterophylla - soybean competition using area of influence methodology under field condition and recorded more reduction in soybean canopy, dry weight (after $6,12,18$ weeks) and yield with 0 to 10 and 10 to $20 \mathrm{~cm}$ distances compared with the 80 to $100 \mathrm{~cm}$ distances from the weed. The degree of weed interference also depends on the density of the weeds infesting the crop. Research conducted by Bridges et al. (1992) indicated that $E$. heterophylla caused a peanut yield loss of 4 to $54 \%$ at densities of 1 to 32 plants per $9 \mathrm{~m}$ of row. Growth (plant height, number of leaves, dry matter accumulation) and macronutrient accumulation of soybean in co-existence with E. heterophylla were reduced with increasing densities of E. heterophylla (Rizzardi et al., 2004; Carvalho et al., 2010). Increase in $E$. heterophylla density from 1 to 10 per pot reduced the growth, yield and yield components of cowpea (Olorunmaiye $\&$ Ogunfolaji, 2002). Yield reduction in cowpea with increasing density of $E$. heterophylla was also reported by Remison (1978). Weed management studies at the International Institute of Tropical Agriculture, Ibadan, Algeria, revealed that a density of 10 plants $\mathrm{m}^{-2}$ of E.heterophylla reduced cowpea yield by $25-53 \%$ while 80 plants $\mathrm{m}^{-2}$ reduced yield by 68-75\% (IITA, 1977).

Jain \& Tiwari (1993) and Mishra \& Singh (2003) advocated that E. geniculata dry weight and density have significant negative correlation with the soybean yield which linearly decreased with increased weed dry weight/density. Increasing densities of E. geniculata from 10 to 120 plants $\mathrm{m}^{-2}$ reduced the seed yield of soybean by $12-30 \%$ and chickpea by $18-53 \%$ in soybean-chickpea cropping system, indicating that at the same density, chickpea was more susceptible to this weed than soybean (Mishra \& Singh, 2003). Euphorbia dentata interference at a density of 20 plants $\mathrm{m}^{-2}$ resulted in a soybean yield reduction of $80 \%$. Seed production decreased by $673 \mathrm{~kg} \mathrm{ha}^{-1}$ for each plant $\mathrm{m}^{-2}$ increase of E. dentata (Juan et al., 2003). Seed cotton yield reduction was 47,57 and $85 \%$ for $E$. maculata densities of 5,10 and 50 plants $\mathrm{m}^{-1}$ of row due to a reduction in growth and yield components of cotton (Bararpour et al., 1994).

The degree of competition offered by a particular weed also depends on associated crops and the behavior of other weeds. Adelusi et al., (2006a,b) reported more competitive behavior of Kersting's ground bean (Macrotyloma geocarpa (Harms) Marechal and Baudet) than E. heterophylla with increasing $\mathrm{N}$ levels as the crop performed better in terms of growth and yield. Similarly, E. heterophylla exhibited less competitive superiority in mixture with Senna obtusifolia (Awodoyin \& Ogunyemi, 2008)

\section{Allelopathic effects of Euphorbia species on field crops}

Several studies have been conducted on the phytotoxicity of Euphorbia species extracts. Aqueous extracts of stems, leaves and roots of leafy spurge inhibited wheat germination and seedling growth of wheat, peas and several other species (Le Tourneau, 1951; Le Tourneau et al., 1956; Le Tourneau \& Haggeness, 1957). Leaves were more toxic than stems and roots (Le Tourneau et al., 1956), which was confirmed later on by Selleck (1972). Variation in the allelopathic response of different plants depends upon the distribution and accumulation of allelochemicals in different parts of weeds. Reduction in seedling growth of maize and wheat, delayed germination, reduced chlorophyll and protein content of wheat with aqueous extract of E. hirta and 
E. hierosolymitana at high concentration has been reported by Jabeen \& Ahmad (2009) and Romman et al. (2010), respectively. The effect of E. hirta on maize was concentration dependent. At low concentration, it promoted seedling growth of maize (Jabeen \& Ahmad, 2009). It means this extract could be used as a growth inhibitor or stimulator for crops depending upon the dose of application.

Aqueous extract of $E$. thiamifolia leaf, stem, root and inflorescence significantly inhibited the germination, seedling growth and weight of Cicer arietinum, Cajanus cajan, Vigna radiata and $V$. uriculata (Kumbhar \& Dabgar, 2010; Kumbhar \& Dabgar, 2011). Effect of E. thiamifolia plant parts was crop dependent. Kumb \& Dabgar (2010) stated that leaf extract had the most inhibitory effect followed by those of the stem, root and inflorescence, on $C$. arietinum, C. cajan, V. radiata and V. uriculata, while Kumbhar \& Dabgar (2011) reported the most inhibitory effect of E. thiamifolia stem followed by those of leaf, inflorescence and root on C. cajan.

Extracts from the root, stem, leaf and fruit of $E$. helioscopia reduced the seed germination of chickpea, lentil and wheat with greater inhibitory effect of leaf (Qasem, 1995; Tanveer et al., 2010). But at low concentration, leaf, stem and root extracts of this weed stimulated seed germination of tested crops as compared to control. It can be concluded that allelochemicals which inhibited germination of some species at certain concentrations, might stimulate the germination of the same or different species at lower concentration.

Tiwari et al. (1985) noted a detrimental effect of root washings of E. hirta on germination and early seedling growth of soybean, groundnut and green gram. Sughar (1979) reported inhibitory effect of $E$. geniculata on wheat.

\section{Allelopathic effects of Euphorbia on other weeds}

Aqueous extract of $E$. granulata significantly inhibited germination and radical growth of Dicanthium annulatum, Cynodon dactylon, Setaria italica, Pennisetum americanum,
Euphorbia pilulifera, Oxalis corniculata and Lactuca sativa (Hussain, 1980). According to Ibrahim et al. (1985), extracts from E. supina, E. pilulifera, E. acalyphoides, E. prunifolia, E. hirta, E. aegyptiaca, E. splendens, and E. granulata were most active in inducing germination of Striga hermonthica seeds. Extracts from $E$. acolyphoides and E. pilulifera were inhibitory at high concentration. Aqueous extract, decaying residues, root extract and soil under E. prostrata stands were inhibitory to seed germination and seedling growth of C. dactylon (Alsaadawi et al., 1990). Olson \& Wallander (2002) reported similar results by recording shorter roots of two perennial grasses (Pseudoroegneria spicata, Pascopyrum smithii) with higher leachate concentrations of E. esula.

\section{Allelopathic effects of Euphorbia infested/rhizosphere soil}

The donor plants release allelochemicals into surrounding environment through leachates, root exudates and volatilization and, hence, accumulation of allelochemicals causes toxicity, affecting crop growth and yield. Field soil samples taken from areas of moderate and high leafy spurge densities or incorporation of leafy spurge leaves, roots or litter into the soil inhibited seedling growth of tomato (Lycopersicon esculentum) and crabgrass (Digitaria sanguinalis. Reduction in frequency and density of quackgrass (Agropyron rapens and common ragweed (Ambrosia artemisiifolia) were noted where leafy spurge had high densities in the field (Steenhagen \& Zimdahl, 1979). Hussain (1980) reported significant germination inhibition and root growth of $D$. annulatum, $C$. dactylon, $S$. italica, P. americanum, E. pilulifera, O. corniculata and $L$. sativa with E. granulata underlying soil. Inhibitory effect of $E$. granulata infested soil was further confirmed by Sadaqa et al. (2010) in onion. Results similar to these findings were reported by Tanveer et al. (2010) for wheat, chickpea and lentil with E. helioscopia.

Inhibitory effect of E. corollata and E. supina on nitrifying bacteria and several strains of $\mathrm{N}$-fixing bacteria in soil was documented by Rice $(1965,1969)$. 


\section{Euphorbia interference in pasture/ rangeland and livestock}

Undesirable plants in grazing land often reduce forage production by competing with native plants and discouraging grazing near the plant, thereby directly affecting the land's usefulness for livestock grazing (Auld et al., 1987; Huenneke, 1995). Leafy spurge is an aggressive perennial weed that readily competes with desirable vegetation in pasture and rangelands (Messersmith, 1983) and decreases herbage production by as much as 75\% (Lym \& Kirby, 1987). Derscheid \& Wrage (1972) and Reilly \& Kaufman (1979) have reported yield reductions of associated desirable forage species from 10 to $100 \%$ with leafy spurge. These losses depend on weed density and competition duration. Lym \& Kirby (1987) experienced a decrease in annual herbage production of at least 35\% in grazed rangelands infested with leafy spurge densities of 50 or more. It tends to displace all other vegetation after establishment in pasture and rangeland habitats (Selleck, 1972; Steenhagen \& Zimdahl, 1979; Lym \& Kirby, 1987) to establish essentially a single species stand through allelopathy by releasing flavanoid compound Kaempherol glucuronide (Selleck et al., 1962), compared to adjacent areas. The plant is toxic to livestock (Selleck et al., 1962) and poses a serious threat to livestock production on open rangelands. Cattle and horses avoid grazing lands of leafy spurge because of chemical irritants in the plant (Muenscher, 1940; Lym \& Kirby, 1987). Although leafy spurge is not utilized by cattle, it is readily grazed by sheep and goats (Landgraf et al., 1984). The latex (milky juice) in leafy spurge is a skin irritant that can cause severe dermatitis in grazing animals (Kingsburry, 1964; Upadhyay et al., 1978). The latex also causes scours and weakness in cattle and may result in death (Muenscher, 1940, 1948, 1960; Kingsbury, 1964). There appear to be many toxic substances in the spurge latex, and the latex has been demonstrated to contain cocarcinogenic factors (Upadhyay et al., 1978).

\section{Euphorbia allelopathy and plant protection}

Many scientists have highlighted the significance of Euphorbia species against insects, virus, fungus and nematodes. Govindaiah et al. (1997) reported that Euphorbia species were least effective against root knot nematode (Meloidogyne incognita) infecting mulberry. On the other hand, Bhatti et al. (1997) reported effective reduction in hatching of larvae of cyst nematodes (Heterodera avenae and $H$. cajani) with Euphorbia hirta. Total larval mortality of Meloidogyne incognita, M. javanica and $M$. arenaria was observed in Euphorbia pilulifera extract (Hussaini et al., 1996). Uma \& Kumar (2009) reported insecticidal property of Euphorbia antiquorum, E. pulcherrina against Plutella xylostella. Inhibitory activity of $E$. hirta, $E$. antiquorum and E. royleana against ride guard mosaic virus has been stated by Tripathi $\&$ Sharma (2007). According to Sahani \& Saxena (2009), E. nerifolia exhibited absolute toxicity $(98.0 \%)$ against Fusarium oxysporum. Antibacterial and antifungal activity of $E$. hirta was also reported by Barate et al. (2008). Effect of $E$. hirta on immune system of poultry was studied by Zafar et al. (2006). Euphorbia hirta leaf extract at lower doses $\left(10 \mathrm{mg} \mathrm{kg}^{-1}\right.$ body weight) acts as an immune potentiator and as an immune suppressor at higher doses (100 $\mathrm{mg} \mathrm{kg}^{-1}$ body weight).

\section{Allelochemicals in Euphorbia species}

The production of phytotoxic natural products by weeds is a mechanism by which these species may become successful competitors. Elmore \& Paul (1983) reported high concentration of phenolics in E. supina and E. maculata, which is supported by previous findings of Rice (1969), who reported phenolics and gallic acid in E. supine. Wanger et al., (1970), Manners \& Wong (1985), Manners (1987), Manners \& Davis (1987) and Qin et al. (2006) have identified several phototoxins, including relatively strong phytotoxins Kaempferol-3-glucuronide and I-hexaconsanol in aqueous extracts of the whole plant, and moderately diterpenes jatrophane in leafy spurge roots. Euphorbia esula (Evans \& Kinghorn, 1977; Roberts \& Olson, 1999; Zhi Qiang et al., 2008) and E. heliescopia (Jiangbo et al., 2010) contains di- and tri- terpenoids and condensed tannins.

This review has concluded that the Euphorbia species if allowed to grow and stand for full or partial life span of the main crop could 
cause a serious impediment in the germination and early seedling establishment of crops and, thus, limit their yield. Furthermore, Euphorbia species have herbicidal and insecticidal properties but there is the need to establish their commercial utility potential as environment friendly plant protection measures.

\section{LITERATURE CITED}

ADELUSI, A. A.; AKAMO, O. A. The combined effects of Euphorbia heterophylla Linn and nitrogen fertilizer on the reproductive yield and competitive ability of Macrotyloma geocarpa (Harms) Marechal and Beaudat. Intern. J. Bot., v. 2 , n. 3, p. 69-73, 2006.

ADELUSI, A. A.; AKAMO, O. A.; MAKINDE, A.M. Nitrogen fertilizer and weed (Euphorbia heterophylla Linn.) effects on the growth parameters of Macrotyloma geocarpa (Harms) Marechal and Beudet. Intern. J. Bot., v. 2, n. 1, p. $74-82,2006 a$.

ADELUSI, A. P.; ODUFEKO, G. T.; MAKINDE, A. M. Interference of Euphorbia heterophylla Linn. on the growth and reproductive yield of soybean (Glycine max (Linn.) Merill. Res. J. Bot., v. 1, n. 2, p. 85-94, 2006 b.

AKOBUNDU, I. O.; AGYAKA, C. N. A handbook of west african weed. Ibadan: International Institute of Tropical Agriculture, 1987. $564 \mathrm{p}$

ALSAADAWI, I. S.; SAKERI, I. A. K.; AL-DULAIMY, S. M. Allelopathic inhibition of Cynodon dactylon (L.) Pers. and other plant species by Euphorbia prostrata L. J. Chem. Ecol., v. 16, n. 9, p. 2747-2754, 1990.

AULD, B. A.; MENZ, L. M.; TISDELL, C. A. Weed control economics. Orlando: Academic Press, 1987. 177 p.

AWODOYIN, R. O.; OGUNYEMI, S. Competitive ability of sicklepod (Senna obtusifolia L.) in combination with Chromolaena odorata (L.) K \& R and Euphorbia heterophylla L. Trop. Agric. Res. Ext., v. 11, n. 1, p. 25-30, 2008.

BANNON, J. S. et al. Weed watch. Weeds Today, v. 8, n. 1, p. 1-12, 1976.

BANNON, J. S.; BAKER, J. B.; ROGARS, R. L. Germination of wild poinsettia (Euphorbia heterophylla).Weed Sci., v. 26, n. 3, p. 221-225, 1978.

BARARPOUR, M.T.; TALBERT, R. E.; FRANS, R. E. Spotted spurge (Euphorbia maculata) interference with cotton (Gossypium hirsutum). Weed Sci., v. 42, n. 4, p. 553$555,1994$.
BARATE, D. L. et al. Antibacterial and antifungal activity of Euphorbia hirta. J. Plant Disease Sci., v. 3, n. 2 , p. 233-234, 2008.

BHARAT, R.; KACHROO, D. Bio-efficacy of herbicides on weeds in wheat (Trititicum aestivum) and its residual effect on succeeding cucumber (Cucumis sativus). Indian J. Agron., v. 55, n. 1, p. $46-50,2010$.

BHARAT, R.; KACHROO, D. Bio-eficiency of various herbicides and their mixtures on weeds and yield of wheat (Trititicum aestivum) under subtropical agro-ecosystem. Indian J. Agron., v. 52, n. 1, p. 53-59, 2007.

BHATTI, D.S.; DUTT, R.; VERMA, K. K. Larval emergence from cysts of Heterodera avenae and $H$. cajani as affected by plant leaf extracts. Indian J. Nematol., v. 27, n. 1, p. $63-69,1997$.

BRIDGES, D. C.; BRECKE, B. J.; BARBOUR, J. C. Wild poinsettia (Euphorbia haterophylla) interference with peanut (Arachis hypogaea). Weed Sci., v. 40, n. 1, p. 37-42, 1992.

CARVALHO, L. B.; BIANCO, S.; GUZZO, C. D. Interference of Euphorbia heterophylla in the growth and macronutrient accumulation of soybean. Planta Daninha, v. 28, n. 1, p. $33-39,2010$.

DALE, J. E.; CHANDLER, J. M. Herbicide crop rotation for Johnson grass (Sorghum halepense) control. Weed Sci., v. 27, n. 5, p. 479-485, 1979.

DERSCHEID, L. A.; WRAGE, L. G. Leafy spurge. Dakota: South Dakota State University, 1972. p. 4. (Ext. FS 449)

DOWNTOWN, W. J. S. Adaptive and evolutionary aspects of $\mathrm{C}^{4}$ photosynthesis. In: HATCH, M. D.; OSMOND, C. B.; SLATYER, R. O. (Ed.). Photosynthesis and

photorespiration. New York: John Wiley \& Sons, 1971. p. 3-17.

DOWNTOWN, W. J. S. The occurance of $\mathrm{C}^{4}$ photosynthesis among plants. Photosynthetica, v. 9, n. 1, p. 96-105, 1975.

DUNN, P. H. The distribution of leafy spurge (Euphorbia esula) and other weedy Euphorbia spp. In the United States. Weed Sci., v. 27, n. 5, p. 509-516, 1979.

ELMORE, C. D.; PAUL. R. N. Phenolic deposits and kranz syndrome in leaf tissues of spotted (Euphorbia maculata) and prostrate (Euphorbia supina) spurge. Weed Sci., v. 31, n. 1, p. 131-136, 1983.

ENIOLA, T. H.; FAWUSI, M. O. A. Allelopathic activities of crude methanol extract of siam weed and wild poinsettia on germination and seedling growth in tomato. Nigerian $\mathbf{J}$.

Weed Sci., v. 2, n. 1-2, p. 15-20, 1989 
EVANS, F. J.; KINGHORN, A. D. A comparative phytochemical study of the diterpenes of some species of the genera Euphorbia and Elaeophorbia (Euphorbicaceae). Bot. J. Linnaean Soc., v. 74, n. 1, p. 23-27, 1977.

GHAFOOR, A.; SHAD, A. R. Fluroxypyr: a barrier against phenoxy herbicide resistant broad leaved weeds. Indian J. Weed Sci., v. 22, n. 3/4, p. 57-62, 1990.

GOVINDAIAH, D. et al. Nematicidal efficacy of organic manures, intercrops, mulches and nematicide against root knot nematode in mulberry. Indian J. Nematol., v. 27, n. 1, p. 28-35, 1997.

HARGER, T. R.; NESTER, P. R. Wild poinsettia: a major soybean weed. Louisiana Agric., v. 23, n. 3, p. 4-7, 1980 .

HUENNEKE, L. F. Ecological impacts of plant invasion in rangeland ecosystems. In: ALIEN PLANT INVASIONS: INCREASING DETERIORATION OF RANGELAND ECOSYSTEM HEALTH SYMPOSIUM, 1995, Phoenix. Proceedings.... Phoenix AZ: 1995. p. 10-14

HUSSAIN, F. Allelopathic effects of Pakistani weeds: Euphorbia granulata Forssk. Oecologia, v. 45, n. 2, p. 267269, 1980.

HUSSAINI, S. S. et al. Toxicity of water soluble leaf extracts against larvae and egg masses of three Meloidogyne species. Indian J. Nematol., v. 26, n. 1, p. 23-31, 1996.

IBRAHIM, N. E. et al. Activity of extracts from Euphorbia species on the germination of Striga species. Weed Res. v. 25, n. 2 , p. $135-140,1985$.

INTERNATIONAL INSTITUTE OF TROPICAL AGRICULTURE - IITA. Annual report. Ibadan: 1977. $1000 \mathrm{p}$.

JABEEN, N.; AHMAD, M. Possible allelopathic effects of three different weeds on germination and growth of maize (Zea mays L.) cultivars. Pak. J. Bot., v. 41, n. 4, p. $1677-1683,2009$.

JAIN, K. K.; TIWARI, J. P. Correlation and regression analysis of soybean-weed ecosystem. Indian J. Weed Sci., v. 25 , n. $3 / 4$, p. $77-80,1993$.

JANGBO H. E. et al. New compounds from Euphorbia helioscopia and absolute configuration determination by computational methods. Bull. Korean Chem. Soc., v. 31, n. 8, p. 2211-2214, 2010.

JOSAN, J. S.; SHARMA, J. N.; MONGA, P. K. Effect of various herbicides on weed population in citrus nursery.

Indian J. Hortic., v. 60, n. 1, p. 45-48, 2003.
JUAN, V. F. et al. Study of Euphorbia dentata in province centre zone of Buenos Aires. Planta Daninha, v. 14. n. 2, p. 102-109, 1996.

JUAN, V. F.; SAINT-ANDRE, H.; FERNANDEZ, R. R. Competition of spurge tooted (Euphorbia dentata) in soybean. Planta Daninha, v. 21, n. 2, p. 175-180, 2003.

KINGSBURY, J. M. Poisonous plants of the United States and Canada. Englewood Cliffs: Prentice-Hall, 1964. 626 p.

KISSMANN, K. G. Plantas infestantes e nocivas. Sao Paulo: BASF Brasileira, 1992. 792 p.

KUMAR, S.; SINDHU, G.; TEJASVI, A. Screening of chilli varieties for management of summer weeds. Allelopathy $\mathbf{J}$., v. 24, n. 1, p. $143-156,2009$.

KUMBHAR, B. A.; DABGAR, Y. B. Effects of aqueous extracts of Euphorbia thiamifolia on seed germination of some pulses. Life Sci. Leaflets, v. 9, n. 2, p. 241-244, 2010.

KUMBHAR, B. A.; DABGAR, Y. B. Allelopathic effects of aqueous extracts of Euphorbia thiamifolia on germination and seedling growth of Cajanus cajan L. J. Biosci. Res., v. 2, n. 2 , p. $62-66,2011$

LANDGRAF, B. K.; FAY, P. K.; HAVSTAD, K. M. Utilization of leafy spurge (Euphorbia esula) by sheep. Weed Sci., v. 32, n. 3, p. 348-352, 1984.

LE TOURNEAU, D. The phytotoxic effects of aqueous extracts of leafy spurge. RESEARCH REPORT, NORTH CENT. WEED CONTROL CONFERENCE, 1951. $181 \mathrm{p}$.

LE TOURNEAU, D.; HEGGENESS, M. G. Germination and growth inhibitors in leafy spurge foliage and quack grass rhizomes. Weeds, v. 5, n. 1, p. 12-19, 1957.

LE TOURNEAU, D.; FAILES, G. D.; HEGGENESS, M. G. The effect of aqueous extracts of plant tissue on germination of seeds and growth of seedlings. Weeds, v. 4, n. 4, p. $363-368,1956$.

LYM, R. G.; KIRBY, D. R. Cattle foraging behavior in leafy spurge (Euphorbia esula) - infested rangeland. Weed Technol., v. 1, n. 4, p. 314-318, 1987.

MANNERS, G. D. The role of phytochemistry in attacking the leafy spurge (Euphorbia esula L.) problem. ACS Symp. Series, 1987. 228 p.

MANNERS, G. D.; DAVIS, G. D. The characterization of esulone $\mathrm{C}$ and chemotaxonomy of jatrophane diterpenes in leafy spurge. Phytochemistry, v. 26, n. 3, p. 327-30, 1987. 
MANNERS, G. D.; WONG, R. Y. The absolute stereochemical characterization of two new jatrophane diterpenes from Euphorbia esula L. Chem. Soc., p. $2075-2081,1985$

MESCHEDE, D. K. et al. Critical period of interference of Euphorbia heterophylla in soybean crop under low seeding rate. Planta Daninha, v. 20, n. 3, p. 381-387, 2002.

MESSERSMITH, C. G. The leaf spurge plant. N.D. Farm Res., v. 40, n. 5, p. 3-7, 1983.

MISHRA, J. S.; SINGH, V. P. Interference of Euphorbia geniculata in soybean-chickpea cropping system. Indian J. Weed Sci., v. 35, n. 3/4, p. 225-227, 2003

MUENSCHER, W. C. Poisonous plants of the United States. New York: Macmillan, 1940. 266 p.

MUENSCHER, W. C. Poisonous plants of the United States. New York: The Macmillan, 1948. 266 p

MUENSCHER, W. C. Poisonous plants of the United States. New York: The Macmillan Company, 1960. 277 p.

NESTER, P. R.; HARGER, T. R.; MCCORMICK, L. L. Weed watch-wild poinsettia. Weeds Today, v. 11, n. 1, p. $24-25,1979$

OLORUNMAIYE, K. S.; OGUNFOLAJ, R. T. Effect of density and duration of Euphorbia heterophylla (L) on the performance of cowpea (Vigna unguiculata) (Walp). NISEB J., v. 2, n. 1, p. 17-22, 2002.

OLSON, B. E.; WALLANDER, R. T. Effects of invasive forb litter on seed germination, seedling growth and survival. Basic Appl. Ecol., v. 3, n. 4, p. 309-317, 2002.

PONIA, S. S.; MALIK, Y. P.; SINGH, B. P. Weed flora of rabi crops in different farming situations in Jind and Bisar Districts of Haryana. Indian J. Weed Sci., v. 28, n. 1\&2, p. 8-10, 1997.

PROCOPIO, S. O. et al. Physiological characteristics of soybean and common bean crops and three weed species. Planta Daninha, v. 22, n. 2, p. 211-216, 2004.

QASEM, J. R. Allelopathic effect of some arable land weeds on wheat (Triticum durum L.): A survey. Dirasat, v. 22, n. 1, p. $81-97,1995$

QIN, B. et al. Phytotoxic allelochemicals from roots and root exudates of leafy spurge (Euphorbia esula L.). Plant Signaling Behav., v. 1, n. 6, p. 323-327, 2006.

RAGHAVENDRA, A. S.; DAS, V. S. R. The occurance of $\mathrm{C}^{4}$ photosynthesis: A supplementary list of C4 plants reported during late 1974 - mid 1977. Photosynthetica, v. 12, n. 2 , p. 200-208, 1978.
RAJPUT, H. D.; SINGH, K.; KUSHWH, S. H. Integrated weed management in chilli (Capsicum annuиm). Indian J. Agron., v. 48, n. 2, p. 136-138, 2003

RAMANJANEYULU, A. V.; SHARMA, R.; GIRI, G. Weed shift in rice based cropping systems. A review. Agric. Rev., v. 27, n. 1, p. 73-78, 2006.

REILLY, W.; KAUFMAN, K. R. The social and economic impacts of leafy spurge in Montana. In: LEAFY SPURGE SYMPOSIUM. BISMARCK NORTH DAKOTA, 1979, Proceedings: 1979. p. 21-24. (Coop Ext. Serv. Fargo)

REMISON, S. V. Performance of cowpea Vigna unguiculata (L.) (Walp) as influenced by weed competition. J. Agric. Sci., v. 90, n. 3, p. 523-530, 1978.

RICE, E. L. Inhibition of nitrogen - fixing and nitrifying bacteria by seed plants. II. Characterization and identification of inhibitors. Physiol. Plant, v. 18, n. 1, p. 255-268, 1965.

RICE, E. L. Inhibition of nitrogen - fixing and nitrifying bacteria by seed plants. III. Inhibitors from Euphorbia supina. Physiol. Plant, v. 22, n. 6, p. 1175-1183, 1969.

RIZZARDI, M. A. et al. Interference of populations of Euphorbia heterophylla and Ipomoea ramosissima isolated or in mixture in soybean crop. Planta Daninha, v. 22, n. 1, p. 29-34, 2004.

ROBERTS, J.; OLSON, B. E. Effect of Euphorbia esula on sheep rumen, microbial activity and mass in vitro. J. Chem. Ecol., v. 25, n. 2, p. 297-314, 1999.

ROMMAN, S. A.; SHATNAWI, M.; SHIBLI, R Allelopathic effects of spurge (Euphorbia hierosolymitana) on wheat (Triticum durum). Am. Eur. J. Agric. Environ. Sci., v. 7 , n. 3 , p. $298-302,2010$

SADAQA, E. A.; BAWAZIR, A. A.; QASEM, J. R Allelopathic activity of some common weeds species in onion fields. Allelopathy J., v. 26, n. 2, p. 175-184, 2010.

SAHANI, R. K.; SAXENA, A. R. Fungitoxic properties of medicinal and aromatic plants against Fusarium oxysporum $\mathrm{f}$. sp. Pisi. Ann. Plant Protec. Sci., v. 17, n. 1, p. 146-148, 2009.

SANDHU, K. S.; SINGH, T.; SINGH, S. Weed composition of maize (Zea mays) fields in Punjab. Indian J. Weed Sci., v. 31, n. 1/2, p. 18-24, 1999.

SELLECK, G. W. The antibiotic effect of plants in laboratory and field. Weed Sci., v. 20, n. 2, p. 189-194, 1972.

SELLECK, G. W.; COUPLAND, R. T.; FRANKTON, C. Leaf spurge in Saskatchewan. Ecol. Monogr., v. 32, n. 1, p. 1-29, 1962. 
SHANEE, S. et al. Phytotoxic effects of Euphorbia dracunculoides: a weed of rainfed chickpea-chickpea cropping system. Spanish J. Agric. Res., v. 9, n. 2, p. 580-588, 2011.

SHI, Y. P.; JA, Z. J. Recent studies on diterpene esters and their bioactivities from Euphorbia genus in China. Chem. J. Chin. Univ., v. 18, n. 7, p. 1107-1112, 1997a.

SINDHU, M.; BIR, S. S. Weed flora of orchards in Patiala District, Punjab. Indian J. Weed Sci., v. 19, n. 1/2, p. 9-19, 1987.

SINGH, D. B. et al. Agro-biodiversity of Bay Islands. Indian J. Plant Genetic Res., v. 13, n. 3, p. 219-225, 2000.

SINGH, I.; AARWAL, S. K. Impcat of nutrient and weed management on weed dynamics in mustard (Brassica juncea L.czern and coss) under dryland conditions. Indian J. Agric. Res., v. 38, n. 2, p. 87-93, 2004.

SINGH, S. et al. Distribution of weed flora of wheat in Haryana. Indian J. Weed Sci., v. 27, n. 3/4, p. 114-121, 1995.

STEENHAGEN, D. A.; ZIMDAHL, R. L. Allelopathy of leafy spurge (Euphorbia esula). Weed Sci., v. 27, n. 1, p. 1-3, 1979.

SUGHAR, S. K. Effect of weed extracts on wheat germination. Sci. Cult., v. 45, n. 1, p. 65-66, 1979.

SZAREK, S. R. The occurance of crassulacean acid metabolism: A supplementary list during 1976 to 1979.

Photosynthetica, v. 13, n. 4, p. 467-473, 1979.

TANVEER, A. et al. Allelopathic potential of Euphorbia helioscopia $\mathrm{L}$. against wheat (Triticum aestivum L.), chickpea (Cicer erietinum L.) and lentil (Lens culinaris Medic.). Turk J. Agric For., v. 34, n. 1, p. 75-81, 2010.
TIWARI, S. P. et al. Allelopathic effects of weeds on soybean, groundnut and green gram. Current Sci., v. 54, n. 9, p. $434-435,1985$.

TRIPATHI, S. C.; SHARMA, G. Inhibition of infectivity of ridge gourd mosaic virus by latex of some angiosperms.

Vegetos, v. 20, n. 1, p. 53-54, 2007.

UMA, M. S.; KUMAR, A. R. V. Laboratory evaluation of some botanicals against diamond back moth, Plutella xylostella L. (Lepidotera: plutellidae). Pest Manag. Hortic. Ecosyst., v. 15, n. 1, p. 41-47, 2009.

UPADHYAY, R. R. et al. Cocarcinogenic and irritant factors of Euphorbia esula L. latex. Tumori, v. 64, n. 1, p. 99-102, 1978.

WAGNER, H. et al. Isolation of Kaempferol-3-B-Dglucoronoide from Euphorbia esula L. Chem. Ber, v. 103, n. 11, p. 3678-83, 1970.

WILLARD, T. S.; GRIFFIN, J. L. Soybean (Glycine max) yield and quality responses associated with Wild Poinsettia (Euphorbia heterophylla) control programs. Weed Technol., v. 7, n. 1, p. 118-122, 1993.

WILLARD, T. S. et al. Interference of wild poinsettia (Euphorbia heterophylla) with soybean (Glycine max). Weed Technol., v. 8, n. 4, p. 679-683, 1994.

YADAV, D. B.; YADAV, A.; PUNIA, S. S. Evaluation of Bispyribac-sodium for weed control in transplanted rice. Indian J. Weed Sci., v. 41, n. 1/2, p. 23-27, 2009.

ZAFAR, A. et al. Effect of Euphorbia hirta leaf extract on immune system of poultry. J. Immunol. Immunopathol., v. 8, n. 1, p. 44-47, 2006.

ZHI-QIANG. L. et al. Ingenane diterpenoids from Euphorbia esula. Phytochemistry, v. 69, n. 3, p. 812-819, 2008. 